\title{
Ausência de anticorpos contra o vírus da síndrome da cabeça inchada em frangos de corte no Planalto Médio do Rio Grande do Sul, Brasil ${ }^{1}$
}

\author{
Absence of antibodies to the swollen head syndrome virus in broiler chickens from the \\ Planalto Médio, RS, Brazil
}

Loreni Boaro $^{2}$ Luiz Carlos Kreutz ${ }^{3}$ Rosangela Poletto $^{4}$ Mauricio Uonfruhauf $^{5}$

\begin{abstract}
Com o objetivo de determinar a prevalência de anticorpos contra o pneumovírus aviário, foram coletadas 960 amostras de soro sangüíneo de 48 lotes de frangos de corte $(20$ amostras/lote). Os lotes analisados eram provenientes de 23 municípios da região do Planalto Médio. A detecção de anticorpos contra o pneumovírus foi feita através de um ensaio imunoenzimáticos comercial (ELISA). Entre as amostras analisadas, somente $5(0,52 \%)$ foram consideradas positivas para a presença de anticorpos contra o pneumovírus aviário. As amostras positivas encontravamse em $5(10,4 \%)$ dos 48 lotes analisados e em $5(21,74 \%)$ municípios distintos. Considerando-se o baixo número de aves reagentes, pode-se especular que, na região estudada, não há pneumovírus aviário e que os frangos positivos poderiam ser considerados "reatores únicos".
\end{abstract}

Palavras-chave: pneumovírus aviário, síndrome da cabeça inchada, sorologia, frangos de corte.

\section{ABSTRACT}

Aiming to detect antibodies to avian pneumovirus, 960 serum samples were collected from 48 chicken broiler flocks (20 samples per flock) pertaining to 23 counties in the Planalto Médio Region of RS. Antibodies were detected using a commercially available ELISA. Among the samples analyzed, only $5(0.52 \%)$ were considered positive to the presence of antibodies to avian pneumovirus. The positive samples were detected in 5 (10.4\%) of the 48 flock studied, and in $5(21.74 \%)$ distinct counties. Considering the low rate of reacting samples, it could be speculated that the region studied might be free of avian pneumovirus and that the positive samples could be considered as single reactors.

Key words: avian pneumovirus, swollen head syndrome, serology, broiler chickens.

A Síndrome da Cabeça Inchada (SCI) é causada por um vírus pertencente à família Paramyxoviridae, gênero metapneumovirus (DANI et al., 1999; COOK \& CAVANAGH, 2002), também denominado de pneumovírus aviário. $\mathrm{O}$ vírus possui envelope lipoprotéico, material genético do tipo RNA de fita simples e estrutura pleomórfica, com diâmetro de 70 a $300 \mathrm{~nm}$ (MURPHY et al., 1999). Em aves adultas e frangos, a SCI caracteriza-se por sinais respiratórios, inchaço da cabeça e edema submandibular (SILVA et al., 1994). Em reprodutoras pesadas, observam-se sinais respiratórias seguidos por desorientação, torcicolo e edema facial uni e bilateral, o qual estendese por toda a cabeça (ARNS \& HAFEZ, 1992). Os prejuízos econômicos devido à SCI são relevantes, dependendo da variação na taxa de mortalidade, diminuição do ganho de peso e postura de ovos (SILVA et al., 1994). Recentemente, o pneumovírus foi isolado no Sudeste do Brasil (ARNS \& HAFEZ, 1995) e estudos

\footnotetext{
${ }^{1}$ Trabalho executado como requerimento da Disciplina de Iniciação à Pesquisa do Curso de Ciências Biológicas, Universidade de Passo Fundo (UPF). Os projetos do Laboratório de Virologia e Imunologia contam com apoio da FAPERGS (proc. 98/1835-3) e Secretaria Estadual de Ciência e Teconologia - Pólo de Alimentos.

${ }^{2}$ Aluna do Curso de Ciências Biológicas, UPF.

${ }^{3}$ Médico Veterinário, MSc., PhD., Professor de Microbiologia, Imunologia e Doenças Infecto Contagiosas, Faculdade de Agronomia e Medicina Veterinária (FAMV), UPF, Campus I, Bairro São José, 99001-970, Passo Fundo, RS. E-mail: lckreutz@upf.tche.br. Autor para Correspondência.

${ }^{4}$ Aluno do Curso de Medicina Veterinária, FAMV, UPF. Bolsista PIBIC/CNPq.

${ }^{5}$ Médico Veterinário, Doux-Frangosul, Passo Fundo, RS
} 
epidemiológicos indicaram haver uma alta prevalência da infecção em frangos, matrizes e aves de postura (ARNS et al., 1997). Até o momento, não existem dados publicados a respeito da presença do vírus no Rio Grande do Sul, embora relatos clínicos sobre problemas respiratórios condizentes com a infecção pelo pneumovírus aviário são freqüentes. No entanto, a importância dessa enfermidade na região do planalto médio somente poderá ser apreciada após a devida comprovação de aves soropositivas ou pelo isolamento do vírus de aves. Considerando-se a freqüência com que frangos de corte apresentam problemas respiratórios e a possibilidade da ocorrência da SCI na região em estudo, o presente trabalho objetivou determinar a prevalência de anticorpos contra o vírus da SCI em frangos de corte no planalto médio do RS.

As amostras de sangue foram coletadas no momento do abate dos frangos. Após a retração do coágulo, o soro sangüíneo foi transferido para um outro frasco e congelado a $-20^{\circ} \mathrm{C}$ até o momento da análise. Um total de 960 amostras de soro foram coletadas, oriundas de 48 lotes (20 amostras por lote) de 23 municípios da região. O número de amostras analisadas foi calculado utilizando-se Win Episcope 2.0 (BLAS et al., 2002), estimando-se uma prevalência de infecção de aproximadamente $10 \%$, com uma confiabilidade de $90 \%$. A detecção de anticorpos contra o pneumovírus foi feita através de um ensaio imunoenzimáticos (ELISA ${ }^{\text {a }}$ - Guildhay Ltd) disponível comercialmente, com sensibilidade de $97,1 \%$ e especificidade de $100 \%$ (Guildhay Ltd). A execução dos testes e interpretação dos resultados foram feitas de acordo com as recomendações do fabricante.

Entre as amostras analisadas, somente 5 $(0,52 \%)$ foram consideradas positivas $(\mathrm{S} / \mathrm{P}>0,181)$ para a presença de anticorpos contra o pneumovírus aviário. As amostras positivas encontravam-se em 5 $(10,4 \%)$ dos 48 lotes analisados em $5(21,74 \%)$ municípios distintos (Tabela 1).

As observações soroepidemiológicas sobre a SCI em frangos de corte, matrizes e aves de postura no Sudeste do país (ARNS et al., 1997) contrastam com a baixa prevalência de anticorpos contra o pneumovírus observadas em frangos de corte analisados nesse estudo (Tabela 1). No entanto, essa diferença pode resultar em função da amostragem e da idade das aves estudadas, das características epidemiológicas e patogênicas do pneumovírus aviário, e do ensaio utilizado (sensibilidade de $97,1 \%$ e especificidade de $100 \%$ ). Assim, é possível que no momento da coleta o nível de infecção no lote encontrava-se no limiar mínimo de detecção o que resultou na detecção de apenas uma ave por lote. Conseqüentemente, a análise sorológica de matrizes e/
Tabela 1 - Prevalência de anticorpos contra o pneumovírus aviário em frangos de corte de diferentes municípios da Região do Planalto Médio do Rio Grande do Sul.

\begin{tabular}{lccc}
\hline Município & $\begin{array}{c}\mathbf{n}^{\mathbf{0}} \text { lotes } \\
\left(\mathbf{n}^{\mathbf{0}} \text { mostras) }\right.\end{array}$ & $\begin{array}{c}\text { Amostras } \\
\text { positivas }\end{array}$ & $\begin{array}{c}\text { Amostras } \\
\text { negativas }\end{array}$ \\
\hline Água Santa & $2(40)$ & - & 40 \\
Camargo & $1(20)$ & - & 20 \\
Ciríaco & $5(100)$ & - & 100 \\
Dois Lajeados & $1(20)$ & 1 & 19 \\
Fagundes Varela & $2(40)$ & - & 40 \\
Gentil & $2(40)$ & - & 40 \\
Guaporé & $1(20)$ & - & 20 \\
Marau & $3(60)$ & 1 & 59 \\
Nova Alvorada & $1(20)$ & - & 20 \\
Nova Araça & $2(40)$ & - & 40 \\
Nova Bassano & $4(80)$ & 1 & 79 \\
Nova Prata & $3(60)$ & - & 60 \\
Paraí & $2(40)$ & - & 40 \\
Sananduva & $3(60)$ & 1 & 59 \\
São Jorge & $2(40)$ & 1 & 49 \\
São Valentin & $1(20)$ & - & 20 \\
Serafina Correia & $1(20)$ & - & 20 \\
Sertão & $1(20)$ & - & 20 \\
Tapejara & $1(20)$ & - & 40 \\
União da Serra & $2(40)$ & - & $\mathbf{9 5 4}$ \\
Vanini & $1(20)$ & - & \\
Vila Serra & $5(100)$ & - & - \\
Vista Alegre & $2(40)$ & - & $\mathbf{5}$ \\
Total & $\mathbf{4 8 ( 9 6 0 )}$ & - & 20 \\
\hline & & - & - \\
\hline
\end{tabular}

ou aves de postura com história clínica de doença respiratória poderia resultar em uma prevalência maior. Por outro lado, embora os dados obtidos indiquem a presença de aves soropositivas, deve-se considerar a possibilidade de que essas aves sejam "reatores únicos", comuns quando do estudo de certas enfermidades através de técnicas sorológicas, por mais específicas e sensíveis que estas técnicas possam ser.

Dessa forma, não é possível afirmar de forma inequívoca que existe atividade viral na região estudada. Além disso, pode-se especular que a ocorrência de doenças respiratórias na região deve-se à presença de outros agentes etiológicos virais, infecções bacterianas, e micoplasmas, comuns em aves criadas de forma intensiva.

\section{FONTES DE AQUISIÇÃO}

${ }^{a}$ ELISA - Guildhay, Surrey, England.

\section{REFERÊNCIAS BIBLIOGRÁFICAS}

ARNS, C.W. et al. Situation of avian pneumovirus in Brazil. Virus Rev \& Res, v.2, n.1-2, p.101-102, 1997. 
ARNS, C. W.; HAFEZ, H.M. Swollen Head Syndrome in poultry flocks in Brazil. Proc 41 ${ }^{\text {st }}$ West Poult Dis Conf, v. 41, p.81-84, 1992.

ARNS, C. W.; HAFEZ, H.M. Isolation and identification of avian pneumovirus from broiler breeders flocks in Brazil. Proc 44 $^{\text {th }}$ West Poult Dis Conf, v.44, p.124-125, 1995.

COOK, J.K.; CANANAGH, D. Deteccion and differentiation of avian penumoviruses (metapneumoviruses). Avian Pathol, v. 31, n.2, p.117-132, 2002

BLAS, I. et al. Win Episcope 2.0, EPIDECON, Borland ${ }^{\circledR}$ y Delphi $^{\mathrm{TM}}$. Capturado em 17 dez. 2002. Online. Disponível na internet: http://www.clive.ed.ac.ed/winepiscope/.
DANI, M.A.C.; DURIGON, E.L.; ARNS, C.W. Molecular characterization of Brazilian avian pneumovirus isolates: Comparison between immunochemiluminescent Southern blot and nested PCR. J Virol Meth, v.79, p.237-241, 1999.

MURPHY, F.A. et al. Paramyxoviridae. In:

Veterinary virology. 3.ed. San Diego: Academic, 1999. Chap.26, p.411-428.

SILVA, E.N.; ARNS, C.W.; SILVA, J. M. L. Observações sobre a síndrome da cabeça inchada em matrizes pesadas no Brasil. Arq Bras Med Vet Zoot, v.46, n.3, p.210-222, 1994. 